\title{
Hubungan Antara Persepsi Terhadap Keadilan Kompensasi dengan Komitmen Organisasi di Hospitality Industry
}

\author{
Kadek Ratih Dwi Oktarini dan Komang Rahayu Indrawati \\ Program Studi Psikologi, Fakultas Kedokteran, Universitas Udayana \\ Ratih.oktarini@yahoo.com
}

\begin{abstract}
Abstrak
Peningkatan turnover setiap tahun pada hospitality industry disebabkan adanya pemberian gaji yang tidak sesuai. Persepsi karyawan terhadap pemberian kompensasi yang tidak sesuai akan menyebabkan menurunnya komitmen karyawan terhadap organisasi sehingga berdampak pada kemunduran organisasi. Maka dari itu penelitian ini bertujuan untuk mengetahui ada hubungan antara persepsi terhadap keadilan kompensasi dengan komitmen organisasi di hospitality industry.

Metodologi penelitian ini merupakan penelitian kuantitatif yang menggunakan metode regresi linier dan teknik two stage cluster sampling sebagai teknik pengambilan sampel. Responden dalam penelitian adalah karyawan pada 6 hotel berbintang, 3 hotel melati, 1 pondok wisata, 3 bar, 2 restoran, 2 rumah sakit dan 4 biro perjalanan wisata berjumlah 189 karyawan.

Alat ukur yang digunakan adalah skala persepsi keadilan kompensasi sebanyak 26 item yang valid dengan validitas item berkisar antara 0,385-0,743 dan koefisien reliabilitas 0,945. Sedangkan pada skala komitmen organisasi terdapat sebanyak 37 item yang valid dengan validitas item berkisar 0,247-0,688 dan koefisien reliabilitas 0,939. Hasil analisis statistik menunjukkan bahwa terdapat hubungan yang positif dan signifikan antara persepsi terhadap keadilan kompensasi dengan komitmen organisasi $(r=0,826, p=0,000)$. Aspek persepsi terhadap keadilan kompensasi adalah pikiran, perasaan serta perilaku karyawan terhadap adanya keadilan dalam pemberian kompensasi. Adapun besar sumbangan efektif yang diberikan persepsi terhadap keadilan kompensasi untuk komitmen organisasi sebesar 68,2\%. Hasil analisis lanjutan menunjukkan bahwa terdapat hubungan yang sangat kuat antara persepsi terhadap keadilan kompensasi dengan komponen komitmen afektif $(\mathrm{r}=0,802)$.
\end{abstract}

Kata kunci: Persepsi terhadap keadilan kompensasi, komitmen organisasi dan hospitality industry

\begin{abstract}
The increase number of turnover each year in hospitality industry causes by inappropriate commission. The employee's perception of inappropriate compensation's issue will decrease a commitment of employee to the organization that will affect to the discharge of organization. This study aiming to see the relationship between perception of compensation's justice with organizational commitment in hospitality industry.

Methodology this study is a quantitative research that used linier regression technique and two stage cluster sampling technique to collect the sampels. The respondents are an employee at 6 hotels, 3 motels, 1 resort, 3 bars, 2 restaurants, 2 hospitals, and 4 travel agents with 189 employees.

Acting as the measuring device in this research is 26 valid items on scale of perception of compensation's justice ranging between 0,385 to 0,743 and the coefficient reliability is 0,945 . While in scale of organizational commitment there were 37 valid items with validity items ranging from 0,247 to 0,688 and the coefficient reliability is 0,939 . The statistic analysis result showed that there a positive relationship and significant between perception of compensation's justice with organizational commitment $(r=0,826, p=0,000)$. The aspects perception of compensation's justice were employee's is a thought, feelings, and behavior about the justice in giving the compensation. The effective contribution to perception of compensation's justice with organizational commitment is 68,2 percent. Futher analysis showed that was a very strongly relationship between perception of compensation's justice with affective commitment component $(\mathrm{r}=0,802)$.
\end{abstract}

Keywords : Perception of compensation's justice, organizational commitment, and hospitality indust 


\section{LATAR BELAKANG}

Perkembangan pariwisata yang pesat di Bali, dapat dilihat dari banyak wisatawan asing maupun wisatawan dosmetik yang datang berkunjung ke Bali. Hal itu menyebabkan industri pariwisata membutuhkan suatu industri yang mampu memberikan pelayanan yang memuaskan terhadap konsumen selama melakukan perjalanan wisata. Hospitality industry merupakan suatu industri yang berbasis keramahtamahan serta mengandalkan pelayanan dalam menjalankan usahanya (Tom Powers \& Clayon, 2001). Ada beberapa jenis hospitality industry yang dikemukakan oleh Morrison (2002) seperti hotel, motel, resort, park, camp, health care, ducation, military, sport, recreation, restaurant, catering, bar, snack bars, transportation, travel agencies, dan retail store.

Dinas Pariwisata Bali (2011) mengatakan, di Bali terdapat 161 hotel bintang dengan jumlah kamar 20753, 1026 hotel melati dengan jumlah kamar 20199, 1016 pondok wisata dengan jumlah kamar 4478, 1645 restoran atau rumah makan dengan kursi 80989, 552 bar, dan 301 biro perjalanan wisata. Banyaknya jenis hospitality industry yang ada menyebabkan persaingan yang kian kompetitif dan menyebabkan para pelaku industri mempunyai tuntutan dalam memberikan pelayanan yang memuaskan kepada konsumen sehingga mereka tidak kehilangan daya saing dalam perkembangan dunia hospitality industry. Namun, tuntutan dalam memberikan pelayanan tersebut menimbulkan masalah pada hospitality industry seperti adanya ketidakmampuan karyawan memenuhi tuntutan kerja yang berat, tanggung jawab yang cukup besar dan jam extra dalam melakukan pekerjaan.

Ketidakmampuan dalam menghadapi tuntutan kerja yang ada menimbulkan kejadian turnover pada organisasi. Turnover merupakan perilaku mengundurkan diri, pindah dari unit perusahaan, kematian anggota organisasi atau pemberhentian kerja (Sullivan, 2005). Turnover pada hospitality industry meningkat setiap tahunnya, seperti yang terjadi di rumah sakit Bali Med pada tahun 2010 mencapai hingga 15,76\% (Prihanjaya, 2011). Hal yang sama juga terjadi di Nusa Dua Beach Hotel \& Spa, pada tahun 2010 karyawan yang keluar dari hotel sebanyak 19 orang dan tahun 2011 meningkat menjadi 39 orang (Human Resources Department Nusa Dua Beach Hotel \& Spa, 2012).

Turnover akan menyebabkan kerugian pada pihak hospitality industry karena terkait dengan biaya yang dikeluarkan perusahaan. Berdasarkan studi awal yang dilakukan peneliti, alasan karyawan hospitality industry melakukan turnover disebabkan oleh adanya pemberian gaji yang ditawarkan lebih besar, adanya promosi kerja yang lebih baik, lingkungan kerja yang tidak nyaman, ingin lebih mudah mengurus anak atau dekat dengan keluarga, ajakan kenalan dekat, dan lokasi tempat kerja yang strategis.
Alasan-alasan karyawan melakukan turnover menandakan bahwa karyawan hospitality industry mempunyai komitmen organisasi yang rendah. Salah satu prediktor turnover yang baik pada hospitality industry adalah komitmen organisasi (Witasari, 2009). Komitmen organisasi menurut Luthan (2006) dan Riggio (2003) merupakan suatu sikap yang dimiliki karyawan dengan menunjukkan penerimaan nilai-nilai dan tujuan organisasi, loyalitas dengan memberikan kontribusi penuh terhadap organisasi serta terus berusaha memihak. Karyawan terlibat penuh dalam kegiatan organisasi sehingga tetap terjaga kesetiaan menjadi anggota organisasi.

Komitmen karyawan pada organisasi akan memberikan keuntungan, seperti berkurangnya kasus kemangkiran, turnover serta mengurangi biaya dalam pemeliharaan SDM. Allen dan Meyer (1996) mengemukakan terdapat 3 komponen komitmen organisasi yaitu komitmen afektif (keterikatan individu secara psikologis/emosional pada organisasi seperti loyalitas, terikat dan sepakat dengan tujuan organisasi), komitmen keberlanjutan (kebutuhan karyawan untuk tetap tinggal di dalam organisasi karena memikirkan kerugian yang akan dikeluarkan jika berhenti bekerja) dan komitmen normatif (kewajiban untuk tetap tinggal di dalam organisasi karena adanya keharusan untuk tetap bertahan dalam organisasi sesuai dengan norma yang berlaku). Karyawan yang memiliki komitmen tinggi akan bekerja dengan hati yang senang tidak memandang pekerjaan sebagai beban yang diberikan kepadanya.

Dalam upaya menciptakan karyawan yang memiliki komitmen organisasi yang tinggi, manajemen perusahaan harus melakukan usaha yang lebih kreatif dan inovasi dalam meningkatkan kualitas SDM. Beberapa faktor yang dikemukakan oleh Mowday, Porter dan Steers (1982) dan Marchington (1992) untuk meningkatkan komitmen organisasi yaitu karakteristik individu (jenis kelamin, masa kerja, usia, status pernikahan, tingkat pendidikan, ras), karakteristik pekerjaan (variasi ketrampilan, kejelasan peran, signifikan tugas, umpan balik dan otonomi), karakteristik struktural (besar/kecilnya organisasi, desentralisasi/sentralisasi, dan peran serikat kerja), pengalaman kerja, kondisi fisik lingkungan kerja, perasaan aman saat bekerja, pemberian gaji yang sesuai, keinginan bekerja pada pemimpin, dan adanya promosi/penghargaan yang diberikan perusahaan.

Sesuai dengan pernyataan di atas, salah satu faktor untuk meningkatkan komitmen adalah memberikan kompensasi berupa gaji, insentif dan tunjangan yang sesuai dengan keinginan dan kebutuhan karyawan. Karyawan juga mengharapkan adanya keadilan dan keterbukaan pada sistem dan proses pemberian kompensasi (Retnaningsih, 2007). Keadilan kompensasi merupakan suatu pemberian kompensasi yang diberikan sebanding dengan pekerjaan yang sama di pasar tenaga kerja eksternal, pekerjaan atau jabatan yang berbeda di dalam sebuah organisasi, dan besar kontribusi 
kinerja, masukan, pendidikan serta pelatihan (Simamora \& Henry, 2004). Individu yang merasakan suatu ketidakadilan akan melakukan tindakan negatif sebagai respon atas perlakuan organisasinya. Apabila tindakan tersebut tidak mengembalikan perlakuan adil dari perusahaan maka karyawan akan cenderung mengambil tindakan untuk mengundurkan diri.

Faktanya Indonesia memiliki tingkat kepuasan yang lebih rendah dalam urusan gaji, yakni hanya 39\%, jauh lebih rendah dibanding negara lain yakni $51 \%$. Hal ini menunjukkan bahwa perusahaan di Indonesia belum mampu mengambil langkah untuk mengatasi kekhawatiran karyawan terkait kompensasi (www.Portalhr.com, 2012). Adanya ketidakpuasan karyawan terhadap kompensasi tesebut merupakan salah satu aspek persepsi yang dikemukan oleh Branca, Woodworth, dan Marquis (dalam Cahyadi, 2007) yaitu aspek afektif. Branca, Woodworth, dan Marquis (dalam Cahyadi, 2007) mengemukakan terdapat 3 aspek persepsi yaitu aspek kognitif (pemikiran-pemikiran dan penilaian karyawan terhadap kompensasi yang diterima), aspek afektif (perasaan-perasaan karyawan mengenai kompensasi yang diterima) dan aspek konatif (kecenderungan untuk berperilaku negatif atau positif yang dilakukan oleh karyawan berkaitan dengan kompensasi yang diterimanya).

Persepsi ketidakadilan terhadap kompensasi yang diterima dapat menimbulkan perilaku negatif karyawan terhadap perusahaan dan dampak job involvement yang bisa dilihat dari komitmen karyawan yang rendah dan akhirnya akan menurunkan prestasi kerjanya (Noe, 1994). Pernyataan di atas sesuai dengan kejadian yang terjadi pada hotel Kuta Paradiso di Kuta, Badung. Beberapa karyawan tidak merasakan kepuasaan saat melakukan pekerjaan. Hal itu disebabkan karena karyawan merasa adanya ketidaksesuaian antara upah yang diterima dengan tuntutan kerja sehingga menyebabkan menurunnya motivasi kerja (Lestari, 2012). Hal yang sama terjadi pada penelitian anonim (2007) yang menemukan bahwa karyawan pada New York Sport Bar And Dinner Restoran memiliki komitmen yang rendah, hal itu ditunjukkan dengan karyawan melanggar peraturan yang telah ditetapkan perusahaan seperti terlambat masuk kerja dan pulang lebih awal sehingga menyebabkan tingkat pelayanan terhadap pelanggan akan menjadi rendah. Perilaku tersebut timbul karena kompensasi yang diberikan kurang sesuai dengan beban kerja serta tidak ada pemberian tunjangan kepada karyawan.

Karyawan yang mempunyai persepsi yang positif terhadap keadilan kompensasi akan menilai kompensasi yang diberikan adil sehingga menunjukkan keinginan karyawan tetap berada dalam organisasi, mempunyai sikap loyalitas serta menerima nilai dan tujuan organisasi. Sebaliknya, karyawan yang mempunyai persepsi negatif terhadap keadilan kompensasi akan berdampak pada psikologis karyawan itu sendiri sehingga menimbulkan keinginan pindah dari perusahaan. Keinginan tersebut tentu tidak mudah untuk dilakukan mengingat berbagai kondisi yang kurang memungkinkan bagi karyawan untuk pindah dari satu perusahaan ke perusahaan lain, misalnya adanya persaingan di pasar kerja yang semakin ketat. Akhirnya bentuk ketidakmampuan karyawan untuk keluar diwujudkan dengan ketidakpedulian terhadap pekerjaan serta tidak merasa bertanggung jawab terhadap kemajuan perusahaan atau dengan kata lain mempunyai komitmen yang rendah terhadap perusahaan.

Tindakan ketidakpedulian karyawan itu tentu saja berdampak pada kerugian perusahaan karena karyawan yang berkomitmen rendah akan menghasilkan kinerja yang buruk. Hal tersebut tentu tidak dapat dibiarkan terjadi terus-menerus karena akan mengakibatkan karyawan tidak mampu mencurahkan jiwa, perasaan dan pikiran untuk kemajuan perusahaan sehingga pada akhirnya pihak hospitality industry akan kehilangan daya saing.

Penelitian lainnya yang terkait adalah penelitian persepsi keadilan kompensasi terhadap komitmen organisasional melalui kepuasan kerja (Rahayu, 2012). Hasil dari penelitian ini adalah terdapat pengaruh antara persepsi keadilan kompensasi dengan komitmen organisasi, namun pengaruh lebih besar terdapat pada persepsi keadilan kompensasi dan kepuasan kerja dengan komitmen organisasional. Sedangkan pada penelitian (Syafrizka \& Alrendia, 2011) menemukan bahwa kepuasaan kompensasi mempunyai hubungan dengan komitmen organisasi namun pada penelitian itu hanya melihat rasa puas karyawan terhadap kompensasi bukan melihat secara keseluruhan hubungan penilaian/pendapat serta perilaku karyawan ketika memperoleh kompensasi yang adil. Berdasarkan pertimbangan tersebut, peneliti ingin mengetahui apakah ada hubungan antara persepsi terhadap keadilan kompensasi dengan komitmen organisasi. Peneliti mengharapkan penelitian ini dapat menambah pengetahuan dalam ilmu psikologi, khususnya psikologi industri dan organisasi terkait persepsi terhadap keadilan kompensasi dan komitmen organisasi. Manfaat praktis dari penelitian ini adalah membantu perusahaan atau organisasi untuk mengevaluasi masalah dan kinerja karyawan terkait persepsi terhadap keadilan kompensasi dan komitmen organisasi. Serta memberikan saran untuk membuat kebijakan yang mampu menumbuhkan persepsi yang positif pada kompensasi yang diberikan dan komitmen karyawan dalam perusahaan sehingga karyawan dapat produktif dalam bekerja.

\section{METODE}

\section{Variabel dan definisi operasional}


Penelitian ini adalah penelitian kuantitatif dengan menggunakan variabel bebas dan variabel tergantung. Variabel bebas merupakan variabel yang mempengaruhi atau yang menjadi sebab perubahan variabel tergantung, dan variabel tergantung adalah variabel yang dipengaruhi atau yang menjadi akibat, karena adanya variabel bebas (Sugiyono, 2011). Variabel bebas pada penelitian ini yaitu persepsi terhadap keadilan kompensasi dan variabel tergantungnya yaitu komitmen organisasi.

Definisi operasional dari variabel persepsi keadilan kompensasi adalah penafsiran atau interpretasi karyawan terhadap kompensasi yang diberikan sudah dilakukan secara adil sesuai dengan kinerja atau kontribusi karyawan terhadap perusahaan, ketentuan pasar tenaga kerja dan sesuai dengan karyawan yang memiliki pekerjaan yang berbeda dalam satu perusahaan. Kompensasi yang diberikan berupa gaji, insentif dan tunjangan. Persepsi terhadap keadilan kompensasi diungkap dengan skala Likert yang disusun berdasarkan aspek-aspek persepsi dari Branca (1965), Woodworth dan Marquis (1961) yaitu, aspek kognitif, aspek afektif, dan aspek konatif. Semakin tinggi skor yang diperoleh mencerminkan semakin positif persepsi terhadap keadilan kompensasi, dan semakin rendah skor yang diperoleh mencerminkan semakin negatif persepsi terhadap keadilan kompensasi.

Komitmen organisasi adalah loyalitas, kesetiaan, kesediaan karyawan untuk tetap berada dalam organisasi, menerima nilai dan tujuan organisasi serta memberikan kontribusi memajukan organisasi. Variabel ini diukur dengan skala komitmen yang menggunakan model Likert yang disusun berdasarkan komponen affective commitment, continuance commitment, dan normative commitment yang dikemukakan oleh Allen dan Meyer (dalam Bakan, Buyukbese \& Ersahan, 2011). Semakin tinggi skor yang diperoleh mencerminkan semakin tinggi komitmen karyawan terhadap organisasi. Demikian pula sebaliknya, semakin rendah skor yang diperoleh mencerminkan semakin rendah komitmen karyawan terhadap organisasi.

\section{Responden}

Populasi adalah wilayah generalisasi yang terdiri atas objek atau subjek yang mempunyai kuantitas dan karakteristik tertentu yang ditetapkan oleh peneliti untuk dipelajari dan kemudian ditarik kesimpulannya (Sugiyono, 2011). Sampel merupakan sebagian dari populasi yang memiliki karakteristik yang relatif sama dan dianggap bisa mewakili populasi (Azwar, 1998). Populasi dalam penelitian ini adalah karyawan yang bekerja di hospitality industry di kawasan Badung dan Denpasar, Bali. Kriteria sampel dalam penelitian ini adalah karyawan hospitality industry yang berusia 20-50 tahun, karyawan tetap dengan minimal masa kerja 2 tahun dan minimal pendidikan SMA/SMK di kawasan Badung dan Denpasar, Bali.

Metode pengambilan sampel yang digunakan dalam penelitian ini adalah two stage cluster sampling. Teknik ini melakukan 2 tahapan sampling yang dilakukan secara random dan berimbang (Nazir, 1988). Pada tahapan pertama, peneliti mengambil secara random 7 jenis hospitality industry dari 17 jenis hospitality industry yang dikemukakan oleh Morisson (2002). Selanjutnya pada tahapan kedua peneliti kembali mengambil secara random perusahaan yang akan digunakan sebagai tempat penelitian berdasarkan jumlah daftar perusahaan hospitality industry yang ada di kawasan Badung dan Denpasar, Bali.

\section{Tempat penelitian}

Responden dalam penelitian ini merupakan karyawan hospitality industry di kawasan Denpasar dan Badung, Bali. Alasan peneliti memilih kawasan Denpasar dan Badung, Bali sebagai tempat penelitian dikarenakan ketersediaan responden serta jumlah sebaran hospitality industry paling banyak berada di kawasan tersebut dibandingkan kawasan lainnya di Bali (Direktori Dinas Pariwisata Bali, 2011). Berdasarkan teknik pengambilan sampel penelitian secara two stage cluster sampling maka terpilih secara random 6 hotel berbintang, 3 hotel melati, 1 pondok wisata, 4 biro perjalanan wisata, 3 bar, 2 restoran serta 2 rumah sakit swasta digunakan sebagai tempat pengambilan sampel. Dalam menentukan jumlah responden pada penelitian ini maka rumus yang digunakan dikemukakan oleh Hague dan Haris (1995) sehingga diperoleh jumlah sampel dalam penelitian adalah 189 karyawan.

\section{Alat ukur}

Skala pengukuran persepsi terhadap keadilan kompensasi dimodifikasi dari skala yang dikemukakan oleh (Cahyadi, 2007). Skala yang diungkap oleh cahyadi (2007) memiliki jumlah item sebanyak 41 dan dimodifikasi oleh peneliti sehingga menjadi 30 item. Skala kedua yaitu komitmen organisasi dimodifikasi dari skala (Bakan, Buyukbese \& Ersahan, 2011). Skala yang hanya terdiri dari pernyataan favorable dengan 23 item dimodifikasi kembali oleh peneliti menjadi sebanyak 40 item dengan mengungkap pernyataan favorable dan unfavorable. Setelah diuji validitas dan reliabilitasnya, item skala persepsi keadilan kompensasi menjadi 26 item dengan validitas data berkisar antara 0,3850,743 dan reliabilitas sebesar 0,945 sedangkan pada skala komitmen organisasi menjadi 37 item dengan validitas data berkisar antara 0,247-0,688 dan reliabilitas sebesar 0,939 . 


\section{Metode pengumpulan data}

Metode pengumpulan data yang digunakan dalam penelitian ini dengan menggunakan 2 kuisioner, yaitu kuisioner persepsi terhadap keadilan kompensasi dan komitmen organisasi. Kuisioner untuk mengukur persepsi terhadap keadilan kompensasi serta komitmen karyawan dalam organisasi tersedia empat pilihan jawaban, yakni 'sangat tidak setuju', 'tidak setuju', 'setuju', dan 'sangat setuju', dalam kuisioner terdapat lembaran identitas responden dan arahan mengenai cara menjawab, responden diwajibkan untuk memilih salah satu dari alternatif jawaban.

\section{Teknik analisis data}

Validitas merupakan tingkat kemampuan suatu alat ukur untuk mengukur apa yang seharusnya di ukur (Sugiyono, 2011). Dalam penelitian ini, uji validitas dilakukan dengan pengujian validitas konstruk dan validitas isi, pengujian validitas konstruk dilakukan dengan mencari koefisien korelasi item total (rix) dengan bantuan perangkat lunak SPSS 16.0. Suatu item dinyatakan memiliki validitas yang baik dapat diketahui menggunakan tabel product moment correlation untuk mengetahui skor rhitung lalu dibandingkan dengan nilai kritis korelasi pearson atau disebut juga sebagai rtabel. Suatu item dapat dinyatakan valid apabila nilai rhitung > rtabel, namun sebaliknya apabila nilai rtabel > rhitung, maka item tersebut dinyatakan tidak valid (Nurgiyantoro, Gunawan, \& Marzuki, 2004). Pengujian validitas isi menggunakan teknik professional judgement, pengujian ini dilakukan minimal oleh 3 orang yang professional di bidangnya dengan menguji item-item skala pengukuran terkait penggunaan tata-bahasa yang kurang efektif kemudian diperbaiki agar skala tersebut dapat dinyatakan valid dalam hal validitas isi.

Metode analisis data menggunakan regresi linier, dengan bantuan program SPSS 16.0. Analisis data ini digunakan untuk mencari arah hubungan antara variabel, sehingga dapat meramalkan atau memprediksi variabel tergantung apabila variabel bebas diketahui (Riduwan \& Sunarto (2009). Analisis regresi linier didasarkan pada hubungan fungsional ataupun kausal satu variabel bebas dan satu variabel tergantung (Sugiyono, 2011).

Dalam melakukan analisis data, terdapat dua syarat yang harus dipenuhi, yaitu dilakukannya uji asumsi berupa uji normalitas dan uji linearitas dengan alat bantu perangkat lunak SPSS 16.0 (Sugiyono,2011). Uji normalitas dilakukan untuk mengetahui normal atau tidaknya sebaran skor variabel persepsi terhadap keadilan kompensasi dan komitmen organisasi (Hadi, 2000). Salah satu uji normalitas yang biasa digunakan dalam penelitian regresi adalah uji One Sample Kolmogorov Smirnov. (Nurgiyantoro, dkk., 2004) mengatakan data berdistribusi normal jika nilai signifikansi lebih dari 0,05 ( $>0,05$ ). Jika kurang dari 0,05 maka data tersebut dinyatakan tidak normal. Uji linieritas dilakukan untuk mengetahui apakah terdapat hubungan yang linier antara kedua variabel penelitian (Sudjana, 2003). Pengujian pada penelitian pada dengan menggunakan compare means-test for linierity dengan taraf signifikansi 0,05 . Dua variabel dikatakan mempunyai hubungan yang linier bila signifikansi kurang dari 0,05 (Nurgiyantoro, dkk., 2004).

\section{HASIL PENELITIAN}

Uji coba alat ukur dalam penelitian ini dilakukan terhadap karyawan yang bekerja pada 2 rumah sakit, 3 hotel melati, 6 hotel berbintang, 1 pondok wisata, 3 bar, 2 restoran dan 4 biro perjalanan wisata yang berada di kawasan Denpasar dan Badung, Bali yang dilaksanakan mulai 19 desember- 10 januari 2013. Uji coba tersebut dilakukan dengan menyebarkan skala kepada 300 responden yang sesuai dengan kriteria sampel, namun hanya terdapat 189 skala yang melakukan pengisian kuisioner secara lengkap. Data yang telah diperoleh akan dianalisis terlebih dahulu untuk mengetahui validitas dan reliabilitasnya. Berdasarkan hasil uji coba item skala persepsi terhadap keadilan kompensasi yang terdiri dari 30 item kepada 189 responden diperoleh koefisien korelasi yang bergerak dari 0,034 sampai 0,715 . Sesuai dengan taraf signifikan 5\% pada tabel korelasi product moment dengan nilai kritis koefisien korelasi (ttabel) sebesar 0,194, menyatakan bahwa suatu item dapat dinyatakan valid apabila nilai rhitung > rtabel, dalam penelitian ini item yang memiliki nilai koefisien korelasi dibawah nilai kritis koefisien korelasi (ttabel) digugurkan, sehingga terdapat 4 item gugur dan 26 item valid pada skala persepsi terhadap keadilan kompensasi, dengan indeks koefisien korelasi yang bergerak dari 0,385-0,743 dengan reliabilitas sebesar 0,945. Sedangkan pada hasil uji coba item skala komitmen organisasi yang terdiri dari 40 item kepada 189 diperoleh koefisien korelasi yang bergerak dari 0,004 sampai 0,666 . Terdapat 3 item yang gugur dan 37 item yang valid pada skala komitmen organisasi,dengan indeks koefisien korelasi yang bergerak dari 0,247-0,688 dengan reliabilitas sebesar 0,939. Hal tersebut menunjukkan bahwa alat ukur persepsi terhadap keadilan kompensasi dan komitmen organisasi dalam penelitian ini memiliki reliabilitas yang baik.

Berdasarkan hasil uji normalitas dengan 189 karyawan, diketahui bahwa sebaran data pada variabel persepsi terhadap keadilan kompensasi memiliki nilai signifikansi (p) 0,458 dan komitmen organisasi dengan nilai signifikansi (p) 0,126 diatas $0,05 \quad(p>0,05)$, sehingga menunjukan bahwa data persepsi keadilan kompensasi dan komitmen organisasi berdistribusi normal. Pada hasil uji linieritas, diketahui bahwa terdapat hubungan yang linier antara persepsi terhadap keadilan kompensasi dengan 
komitmen organisasi dengan nilai signifikansi (p) 0,000 atau $(\mathrm{p}<0,05)$, sehingga menunjukkan bahwa kedua variabel bersifat linier.

Setelah kedua asumsi untuk melakukan analisis data telah dipenuhi, dilanjutkan dengan uji hipotesis untuk melihat apakah model garis linier dapat dipakai dalam penelitian ini dengan menggunakan uji $\mathrm{F}$ yang dapat dilihat pada tabel hasil analisis regresi :

Tabel 1.
Hasil Analisis Regresi Sederhana Variabel
\begin{tabular}{lcc}
\hline Model & F & Sig \\
\hline Regression & 400,654 & 0,000 \\
\hline Residual & \\
\hline Total & \\
\hline
\end{tabular}

Uji $\mathrm{F}$ dalam penelitian ini menghasilkan Fhitung 400,654 dengan tingkat signifikansi 0,000 ( $\mathrm{p}<0,05)$, maka dengan hasil tersebut diketahui bahwa garis model regresi ini dapat dipakai untuk memprediksi komitmen organisasi dengan prediktornya adalah persepsi terhadap keadilan kompensasi.

Tabel 2.

\begin{tabular}{lccccc}
\multicolumn{7}{c}{ Persamaan Garis Regresi dan Hasil Uji T } \\
\hline \multirow{2}{*}{ Model } & \multicolumn{2}{c}{$\begin{array}{c}\text { Unstandardized } \\
\text { coefficient }\end{array}$} & $\begin{array}{c}\text { Standardized } \\
\text { coefficient }\end{array}$ & & \\
\cline { 2 - 6 } & $\mathrm{B}$ & Std.error & $\mathrm{B}$ & $\mathrm{t}$ & Sig. \\
\hline Konstanta & 32,683 & 3,602 & & 9,074 & 0,000 \\
\hline Ykomitmen & 0,968 & 0,048 & 0,826 & 20,016 & 0,000 \\
\hline
\end{tabular}

Berdasarkan hasil analisis data, diperoleh nilai ttabel $(1,960)<$ thitung $(20,016)$ dengan nilai signifikansi p sebesar $0,000(\mathrm{p}<0,05)$ sehingga dapat disimpulkan bahwa terdapat hubungan positif antara persepsi terhadap keadilan kompensasi dengan komitmen organisasi, sehingga hipotesis alternatif (Ha) yang berbunyi "ada hubungan positif antara persepsi terhadap keadilan kompensasi dengan komitmen organisasi" dapat diterima. Pada tabel di atas dapat dilihat persamaan garis regresi pada hubungan kedua variabel tersebut adalah $\mathrm{Y}=32,683+0,968 \mathrm{X} \pm 9,649$. Beta sebesar 0,968 menyatakan bahwa setiap penambahan satu nilai persepsi terhadap keadilan kompensasi, akan meningkatkan komitmen organisasi sebesar 0,968. Tanda positif menyatakan bahwa hubungan variabel bebas dengan variabel terikat searah, yakni setiap kenaikan atau penurunan variabel persepsi terhadap keadilan kompensasi (X) akan mengakibatkan kenaikan atau penurunan variabel komitmen organisasi (Y).

\begin{tabular}{cccc}
\multicolumn{5}{c}{ Tabel 3. } \\
Koefisien Determinasi Penelitian \\
\hline$R$ & Rsquare & $\begin{array}{c}\text { Adjusted } R \\
\text { square }\end{array}$ & $\begin{array}{c}\text { Std. error of } \\
\text { the estimate }\end{array}$ \\
\hline 0,826 & 0,682 & 0,680 & 9,649 \\
\hline
\end{tabular}

Hasil analisis di atas menunjukkan nilai KD (koefisien determinasi) bahwa variabel bebas (persepsi terhadap keadilan kompensasi) memiliki kontribusi sebesar $68,2 \%$ terhadap variabel tergantung (komitmen organisasi) dan $32,8 \%$ dipengaruhi oleh hal-hal selain variabel (persepsi terhadap keadilan kompensasi) seperti yang sudah peneliti paparkan di dalam bab II. Nilai adjusted R Square sebesar 0,680 mengandung makna bahwa apabila model regresi diterapkan pada populasi, maka kontribusinya adalah sebesar $68 \%$.

Terkait dengan adanya hubungan positif antara persepsi terhadap keadilan kompensasi dengan komitmen organisasi dapat diperjelas dengan adanya pengkategorian kelompok yang memiliki skor persepsi terhadap keadilan kompensasi dan komitmen organisasi dari yang paling tinggi hingga yang paling rendah. Pengkategorian ini dilakukan dengan menggunakan rumus pengkategorian skor dari Azwar (2000).

Tabel 4

\begin{tabular}{cccrc}
\multicolumn{5}{c}{ Tabel 4. } \\
& \multicolumn{4}{c}{ Kategorisasi skor persepsi terhadap keadilan kompensasi } \\
\hline Variabel & Rentang Nilai & Kategon & Responden & Persentase \\
\hline Persepsi & $\mathrm{X} \leq 45,5$ & Sangat Negatif & 10 orang & $5,3 \%$ \\
\cline { 2 - 5 } terhadap & $45,5 \leq \mathrm{X} \leq 55,5$ & Negatif & 7 orang & $3,7 \%$ \\
\cline { 2 - 5 } keadilan & $55,5 \leq \mathrm{X} \leq 65,5$ & Sedang & 40 orang & $21,2 \%$ \\
\cline { 2 - 5 } kompensasi & $65,5 \leq \mathrm{X} \leq 79,5$ & Positif & 76 orang & $40,2 \%$ \\
\cline { 2 - 5 } & $79,5<\mathrm{X}$ & Sangat positif & 56 orang & $29,6 \%$ \\
\hline & Jumlah & & 189 orang & $100 \%$ \\
\hline
\end{tabular}

Tabel di atas menjelaskan bahwa rata-rata karyawan hospitality industry memiliki persepsi yang positif terhadap keadilan kompensasi, dimana dari 189 karyawan yang menjadi responden penelitian terdapat 76 karyawan yang memiliki skor persepsi keadilan kompensasi yang berada di kategori positif.

Tabel 5

Kategorisasi Responden pada Skala Komitmen organisasi

\begin{tabular}{ccccc}
\multicolumn{5}{c}{ Kategorisasi Responden pada Skala Komitmen organisasi } \\
\hline Variabel & Rentang Nilai & Kategori & Responden & Persentase \\
\hline \multirow{4}{*}{$\begin{array}{c}\text { Komitmen } \\
\text { organisasi }\end{array}$} & $\mathrm{X} \leq 63,25$ & Sangat Rendah & 5 orang & $2,6 \%$ \\
\cline { 2 - 5 } & $63,25 \leq \mathrm{X} \leq 83,5$ & Rendah & 12 orang & $6,3 \%$ \\
\cline { 2 - 5 } & $83,5 \leq \mathrm{X} \leq 101,25$ & Sedang & 71 orang & $37,6 \%$ \\
\cline { 2 - 5 } & $101,25 \leq \mathrm{X} \leq 120,75$ & Tinggi & 75 orang & $39,7 \%$ \\
\cline { 2 - 5 } & $120,75<\mathrm{X}$ & Sangat Tinggi & 26 orang & $13,8 \%$ \\
\hline Jumlah & & 189 orang & $100 \%$ \\
\hline
\end{tabular}

Berdasarkan tabel di atas, maka dapat dijelaskan bahwa rata-rata karyawan hospitality industry memiliki komitmen organisasi yang tinggi, dimana dari 189 karyawan terdapat 75 karyawan memiliki skor komitmen organisasi yang berada di kategori tinggi.

\section{PEMBAHASAN DAN KESIMPULAN}

Perusahaan hospitality industry membutuhkan karyawan yang mempunyai dedikasi tinggi terhadap perusahaan agar mampu meningkatkan daya saing antar pelaku hospitality industry. Agar memiliki karyawan yang mampu meningkatkan komitmen dan kinerjanya, perusahaan dapat memberikan gaji dan insentif yang sesuai dengan pasar tenaga kerja sehingga karyawan dapat merasakan kepuasaan terhadap tunjangan yang diberikan (Bagyo, 2009). Singodimedjo dan Markum (2000) untuk mempertahankan karyawan agar tidak meninggalkan organisasi dapat dilakukan dengan memberikan kompensasi yang adil. Ada hal yang lebih penting dari sekedar memberikan kompensasi berdasarkan kriteria kerja yaitu persepsi karyawan terhadap kompensasi 
yang diterima (Robbins, 2006). Kompensasi yang diberikan oleh perusahaan akan menimbulkan suatu persepsi dalam bentuk pikiran, perasaan serta kecenderungan berperilaku. Luk \& Chie (dalam Suhartini, 2009) mengatakan ketika perhatian organisasi terfokus untuk menciptakan keadilan individual, internal dan eksternal dari kompensasi finansial maupun nonfinasial seperti gaji, insentif dan tunjangan akan mampu menarik, mempertahankan dan memotivasi karyawan untuk mencapai kepuasaan diri, meningkatkan kinerja dan survive dalam organisasi.

Karyawan yang mempunyai persepsi yang negatif terhadap keadilan kompensasi maka akan menyebabkan menurunnya kepuasaan kerja dan meningkatnya turnover serta absenteeism. Adanya turnover dan absenteeism tinggi mengindikasikan kemungkinan karyawan memiliki komitmen yang rendah. Persepsi negatif terhadap pemberian kompensasi yang diterima, menandakan karyawan mengalami ketidakpuasan terhadap kompensasi yang diterima, karyawan cenderung mempunyai keyakinan, pemikiran dan pendapat bahwa perusahaan memberikan kompensasi yang tidak sesuai dengan kontribusi kinerjanya sehingga berdampak pada pelayanan yang buruk terhadap konsumen, kecenderungan untuk pindah ke perusahaan lain, dan sering mangkir dari pekerjaan. Pernyataan tersebut diperkuat oleh Noe (1994) yang mengatakan rasa tidak puas terhadap kompensasi yang diberikan tidak akan menghasilkan perilaku positif dan tingkat komitmen karyawan terhadap organisasi akan menjadi rendah. Rasa tidak puas merupakan salah satu bentuk aspek afektif persepsi karyawan terhadap keadilan pemberian kompensasi oleh perusahaan.

Sumbangan efektif dari persepsi terhadap keadilan kompensasi terhadap komitmen organisasi sebesar 68,2\% dan sisanya terdapat $32,8 \%$ dipengaruhi oleh hal-hal lain di luar persepsi terhadap keadilan kompensasi. Menurut asumsi dari peneliti berdasarkan teori-teori yang sudah dikemukakan di bab II, variabel lain yang mempengaruhi komitmen organisasi karyawan yang bekerja di hospitality industry adalah karakteristik individu itu sendiri berupa usia, jenis kelamin, masa kerja, ras, minat, sikap, kebutuhan, tingkat pendidikan dan motif berprestasi.

Pada penelitian ini peneliti ingin melihat hubungan karakteristik individu seperti jenis kelamin, status pernikahan, usia, masa kerja dan pendidikan dengan komitmen organisasi yang diperoleh berdasarkan data demografis. Berdasarkan analisis uji chi-square diperoleh nilai probabilitas sebesar $0,398$ ( $p>0,05)$ pada jenis kelamin dengan komitmen organisasi maka dapat dinyatakan bahwa tidak terdapat hubungan antara jenis kelamin dengan komitmen organisasi. Hal tersebut sesuai dengan penelitian Edowati (1992) yang menyatakan bahwa tidak ada hubungan antara jenis kelamin dengan komitmen karyawan pada organisasi. Nina (1996) mengatakan bahwa status pernikahan tidak berhubungan dengan komitmen organisasi. Dalam penelitian ini berdasarkan analisis uji chi-square, peneliti menemukan nilai probabilitas 0,599 ( $p>0,05)$ sehingga dapat dinyatakan bahwa pada penelitian ini juga tidak ditemukan hubungan antara status pernikahan terhadap komitmen organisasi pada karyawan hospitality industry.

Berdasarkan analisis uji spearman-rho peneliti juga tidak menemukan adanya hubungan antara tingkat pendidikan dengan komitmen organisasi dalam penelitian ini. Hal itu dapat dilihat berdasarkan nilai koefisien korelasi 0,03 dengan probabilitas sebesar 0,685 ( $p>0,05)$, sehingga sesuai dengan penelitian Martono (1997) yang menemukan bahwa tidak ada pengaruh tingkat pendidikan terhadap komitmen organisasi.

Peneliti menemukan hubungan antara usia dan masa kerja dengan komitmen organisasi pada karyawan hospitality industry, hal itu dapat dilihat dari analisis uji product-moment yang memperoleh nilai koefisien korelasi sebesar 0,419 dan probabilitas 0,000 antara usia dengan komitmen organisasi serta nilai koefisien korelasi 0,330 dengan propabilitas 0,000 antara masa kerja dan komitmen organisasi. Hal ini sesuai dengan pernyataan Robbins (2006) yang mengatakan semakin tua usia karyawan, makin tinggi komitmennya terhadap organisasi. Adanya keterbatasan usia sehingga kesempatan untuk mencari pekerjaan ditempat lain tidaklah ada. Komitmen karyawan pada usia yang lebih muda, biasanya mempunyai sikap kurang disiplin, kurang bertanggungjawab dan sering berpindah-pindah pekerjaan (Nitisemito, 2000). Kreitner dan Kinicki (2004) menyatakan bahwa seseorang yang memiliki masa kerja yang lama memiliki waktu yang cukup lama untuk menyesuaikan diri dengan pekerjaan dan lingkungan kerja sehingga timbul kenyamanan dan cenderung betah bertahan didalam perusahaan.

Komitmen dalam organisasi juga dipengaruhi oleh karakteristik pekerjaan seperti kejelasan peran, variasi ketrampilan dalam menghadapi tantangan pekerjaan, signifikan tugas, kesempatan berinteraksi, otonomi dan umpan balik juga mempengaruhi terjadinya komitmen. Individu yang mengalami pengalaman kerja lebih lama dalam perusahaan akan membuat individu terbiasa dan mampu bekerja lebih produktif. Tobing (2009) mengatakan bahwa pengalaman kerja merupakan kekuatan sosialisasi yang dapat mempengaruhi kelekatan psikologis karyawan terhadap perusahaan, hal ini menandakan karyawan akan memiliki komitmen yang tinggi ketika mempunyai pengalaman kerja yang cukup lama.

David (dalam Sopiah, 2008) menambahkan seseorang yang memiliki komitmen organisasi tergantung dari besar atau kecil perusahaan tempatnya bekerja, bentuk organisasinya sentralisasi atau desentralisasi serta peranan serikat pekerja yang ada di perusahaannya. Karyawan juga akan meningkatkan semangat kerja ketika berada di lingkungan tempat kerja berkualitas yang menimbulkan rasa 
nyaman, tentram (Sihombing, 2004). Perasaan atau keinginan untuk bekerja pada pemimpin atau perusahaan yang sudah diketahui mempunyai latar belakang yang baik juga dapat menumbuhkan rasa komitmen karyawan terhadap organisasi (Marchington, 1992). Greenglass, Burke dan Fiksenbaum (dalam Nugraha, 2010) mengatakan bahwa pengaruh ketidakamanan kerja (job insecurity) terhadap karyawan menyebabkan komitmen rendah serta jumlah karyawan yang berpindah (employee turnover) akan meningkat. Luthan dan Ganzach (dalam Muhadi, 2007) yang menyatakan bahwa kepuasaan karyawan terhadap promosi yang diberikan akan menyebabkan komitmen karyawan terhadap organisasi bertumbuh dengan baik.

Ada hubungan yang sangat kuat antara persepsi terhadap keadilan kompensasi dengan komitmen afektif dibandingkan komitmen normatif dan komitmen keberlanjutan yang dapat dilihat dari uji analisis product-moment dengan hasil koefisien korelasi antara persepsi terhadap keadilan kompensasi dengan komitmen afektif sebesar 0,802 lebih besar dibandingkan korelasi antara persepsi terhadap keadilan kompensasi dengan komitmen normatif sebesar 0,723 dan persepsi terhadap keadilan kompensasi dengan komitmen keberlanjutan sebesar 0,703. Hasil korelasi tersebut menandakan bahwa karyawan yang merasa pengalokasian imbalan pada perusahaan diberikan secara adil, maka karyawan akan cenderung setia pada perusahaan karena telah memiliki keterikatan emosional dengan perusahaan dan merasa bahwa perusahaan tersebut sesuai dengan nilai dan tujuan perusahaan (Hasmarini \& Yuniawan, 2008).

Dalam penelitian ini karyawan hospitality industry rata-rata memiliki persepsi yang positif terhadap keadilan kompensasi, hal itu dapat dilihat dari perbandingan mean teoritis dan empiris, nilai mean teoritis 65 lebih kecil dibandingkan mean empiris 73,04 sehingga menunjukkan karyawan hospitality industry rata-rata memiliki tingkat persepsi keadilan kompensasi yang positif. Karyawan hospitality industry yang menjadi responden dalam penelitian ini juga memiliki rata-rata tingkat komitmen organisasi yang tinggi, hal itu ditunjukkan dari mean teoritis 92,5 lebih kecil dibandingkan mean empiris 103,40.

Berdasarkan hasil dan pembahasan maka dapat disimpulkan bahwa ada hubungan yang positif dan signifikan antara persepsi terhadap keadilan kompensasi dengan komitmen organisasi. Namun ada juga faktor-faktor lain yang dapat mempengaruhi komitmen karyawan terhadap organisasi seperti karakteristik individu antara lain (jenis kelamin, masa kerja, usia, status pernikahan, tingkat pendidikan, ras), karakteristik pekerjaan (variasi ketrampilan, kejelasan peran, signifikan tugas, umpan balik dan otonomi), karakteristik struktural (besar/kecilnya organisasi, desentralisasi/sentralisasi, dan peran serikat kerja), pengalaman kerja, kondisi fisik lingkungan kerja, perasaan aman saat bekerja, keinginan bekerja pada pemimpin, dan adanya promosi/penghargaan yang diberikan perusahaan.

Saran praktis untuk karyawan hospitality industry dengan memberikan hasil penelitian ini sebagai bahan advokasi untuk melakukan kolaborasi antara serikat pekerja dengan pimpinan dalam membuat kebijakan kompensasi yang adil dan terbuka. Peneliti menyarankan untuk perusahaan agar memberikan insentif yang konsisten terhadap karyawan, promosi kerja serta memberikan voucher hiburan atau mengadakan wisata bersama (family gathering), memberikan survey kecil kepada karyawan secara berkala minimal sebulan sekali untuk memperoleh feedback dari karyawan sekaligus sebagai wadah bagi karyawan dalam memberi masukan berkaitan dengan perkembangan perusahaan dan menciptakan program-program penghargaan bagi karyawan yang memiliki prestasi seperti employee award yang diadakan setiap tahun.

Ada upaya lain yang dapat dilakukan perusahaan untuk meningkatkan komitmen karyawan dalam organisasi, menurut Marpaung (2010) pihak perusahaan dapat membuat suatu program yang didesain untuk mempererat kerja sama team dalam pencapaian tujuan-tujuan organisasi seperti Achieving Together Process (ATP), program yang mampu menampung dan menghargai ide-ide kreatif karyawan untuk mencapai peningkatan kinerja yang berkelanjutan serta membuat program yang didesain agar karyawan dapat bertatap muka dan berdialog secara langsung dengan pemimpin perusahaan sehingga mendapatkan informasi baru tentang perkembangan perusahaan yang dinamakan Town Hall + Reach out. Program-program itu tentu tidak hanya menimbulkan persepsi yang positif terhadap keadilan kompensasi, tetapi juga akan menimbulkan persepsi yang positif terhadap keadilan dalam organisasi.

Saran untuk peneliti selanjutnya agar lebih memperhatikan variabel lain yang terkait dalam meningkatkan komitmen karyawan pada hospitality industry selain dengan adanya persepsi yang positif terhadap keadilan kompensasi, lalu memperhatikan kriteria-kriteria dalam pemilihan responden yang memberi pengaruh penting pada variabel dependent sehingga dapat dilakukan kontrol, menggunakan analisis statistik lain (regresi ganda atau menggunakan uji komparasi) dan menambah instrumen penelitian dengan metode wawancara atau observasi untuk dapat mengukur variabel penelitian lebih dalam.

\section{DAFTAR PUSTAKA}

Allen, N. J., \& Meyer, J.P. (1996). Commitmen in the workplace theory research and application. California: Sage Publications.

Arikunto, S. (2006). Prosedur penelitian suatu pendekatan praktik. Jakarta: PT Remaja Cipta. 
Azwar, S. (1998). Metodologi penelitian, Pustaka Pelajar : Yogyakarta

Azwar, S. (2012). Penyusunan skala psikologi edisi kedua. Yogjakarta: Penerbit Pustaka Pelajar.

Bagyo, Yupono. (2008). Komitmen organisasi merupakan variabel mediasi hubungan kompensasi finansial dan kompensasi non finansial terhadap kinerja karyawan (Studi pada Karyawan PT Bank UOB Buana Capem Tabanan-Bali). STIE Malangkucecwara Malang, Malang.

Bakan, I., Buyukbese, T., \& Ersahan, B. (2011). An investigation of organizational commitment and education level among employees. International journal of emerging sciences.

Bali, D. P. P. (2011). Direktori pariwisata provinsi bali 2011. Bali.

Boediono., \& Koster, W. (2004). Teori dan Aplikasi Statistika dan Probabilitas. Bandung: PT Remaja Rosdakarya.

Branca, A. (1965). Psychology the sicence of behariover. Usa: allyn and bacon, inc.

Cahyadi, A. (2007). Hubungan antara persepsi terhadap keadilan kompensasi dengan kepuasan kerja karyawan Pt. Enseval Putera Megatrading Tbk.Cabang Semarang. Universitas Diponegoro, Semarang.

Edowati, D. (1992). Iklim organisasi, nilai individu, dan komitmen terhadap organisasi: Suatu studi perbandingan pada bank pemerintah dan bank swasta asing di Jakarta. Skripsi Fakultas Psikologi Universitas Indonesia, Depok.

Ghozali, I. (2006). Aplikasi analisis multivariate dengan program spss. Semarang: Badan Penerbit Universitas Diponegoro

Hadi, S. (2000). Metodologi research. Yogjakarta: Andi.

Hague, P., \& Haris, P. (1995). Sampling statistika. Jakarta: PT. Pustaka Binaman Pressindo.

Kreitner, R., \& Kinichi, A. (1998). Organizational behavior 4nd edition. Homewood: Illionis: Richard D. Irwin, Inc.

Lestari, I. (2012). Pengaruh kepemimpinan, kompensasi finansial, program keselamatan dan kesehatan kerja pada hotel kuta paradiso di kuta, badung. Universitas Warmadewa, Denpasar.

Luthans, F. (2006). Perilaku organisasi. Yogyakarta: Andi.

Marchington. (1992). Managing the team : A guide to succesful employee involvement. Massachusetts: BlackWell Business

Marpaung, R. (2010). Peran penting "employee engagement" dalam keberhasilan organisasi (bagian 2 dari 2 tulisan). Retrieved from http://www.rachmatmarpaung.com/2010/10/peranpenting-employee-engagement-dalam_27.html
Martono, Ilma. (1997). Hubungan antara iklim organisasi dengan keterikatan terhadap organisasi: studi pada karyawan perusahaan "x". Fakultas Psikologi Universitas Indonesia, Depok.

Mowday, R.T., Porter, L.W., \& Steers, R.M. (1982). Employeeorganization linkages: thepsychology of commitment, absenteeism, and turnover. New York: Academic Press.

Muhadi. (2007). Analisis pengaruh kepuasan kerja terhadap komitmen organisasional dalam mempengaruhi kinerja karyawan. Universitas Diponegoro, Semarang.

Nina, A. (1996). Hubungan antara persepsi karyawan dan diskrepansi harapan-persepsi karyawan terhadap pengelolaan sumber daya manusia dalam organisasi dengan komitmen karyawan pada organisasi. Universitas Indonesia, Depok.

Nitisemito, Sumaji. (2000). Perilaku organisasi perusahaan, Salemba Empat,Jakarta.

Noe, (1994). Human resources management : Going a competitive advantage: Riehard d. Irwin. Inc.

Nugraha, A. (2010). Analisis pengaruh ketidakamanan kerja dan kepuasan kompensasi terhadap kinerja karyawan.Universitas Diponegoro, Semarang.

Nurgiyantoro, B., Gunawan, \& Marzuki. (2009). Statistik terapan ( Untuk penelitian ilmu-ilmu sosial). Yogjakarta: Gadjah Mada University Press.

Portalhr. (2012, 28-09-2012). Gaji, masih penting dalam menarik dan mempertahankan karyawan. Retrieved from http://www.portalhr.com/berita/gaji-masih-penting-dalammenarik-dan-mempertahankan-karyawan/

Rahayu, W. (2012). Persepsi keadilan kompensasi terhadap komitmen organisasional melalui kepuasan kerja. jurnal manajemen bisnis, volume 2 .

Retnaningsih, S. (2007). Analisis pengaruh keadilan kompensasi, peran kepemimpinan, dan kepuasan kerja terhadap komitmen organisasi dalam meningkatkan kinerja karyawan studi kasus: pada sentral pengolahan pos semarang). Universitas Diponegoro, Semarang

Riggio, R. E. (2003). Introduction to industryal/organizational psychology. New Jersey: Prentice Hall.

Simamora, \& Henry. (2004). Manajemen sumber daya manusia. Yogyakarta: BTSTIEYKPN

Singodimedjo, \& Markum. (2000). Manajemen sumber daya manusia. Surabaya: SMMAS

Sopiah. (2008). Perilaku organisasi. Yogyakarta: Andi. 
Sudjana. (2003). Metoda statistika. Bandung: Tarsito

Sugiyono, (2011). Statistika untuk penelitian. Bandung: Alfabeta

Sullivan, K.T, (2005), Impact of extended overtime on construction labor productivity. Journal of construction engineering and management. Volume 131, Issue 6, pp. 734-739

Syafrizka, \& Alrendia. (2011). Hubungan kepuasaan kompensasi dengan komitmen organisasi. Universitas Sumatera Utara, Medan.

Tobing, M. R. L. (2009/2010). Perbedaan Komitmen Organiasasi Pada Perawat Ditinjau Dari Jenis Rumah Sakit. Universitas Sumatera Utara, Medan.

Tom Powers, \& Clayon. (2001). Introduction to the hospitality industry. New York: Library of Congress Cataloging.

Witasari, L. (2009). Analisis pengaruh kepuasan kerja dan komitmen organisasional terhadap turnover intention(studi empiris pada novotel semarang). UniversitasDiponegoro, Semarang.

Woodworth, Robert, S., Marquis, \& Donald, G. (1961). Psychology. New York: Holt, Rinehart and Winston, Inc. 